\title{
Polanyi's embeddedness and shareholder stewardship: a contextual analysis of current Anglo-American perspectives on corporate governance
}

LORRAINE E TALBOT ${ }^{1}$

University of Warwick

\begin{abstract}
Polanyi saw the economy as properly embedded in society and argued that the capitalist free market, in commodifying social relations of production, seeks to disembed the economy from society. The resulting lack of continuity between society and economy, he maintained, created conflict which necessarily required state intervention. The market economy, therefore, in contrast to neoclassical/ neoliberal economics' vision of an autonomous, self-regulating market, required more, not less, state intervention to sustain it than alternative, more embedded economies. This article explores this conflict in the context of a specific neoliberal claim: that institutional shareholders are capable of being good "stewards" of the companies in which they invest. Utilising Polanyi's embeddedness, this article assesses the "stewardship" approach as it is manifested in the US and in the UK. This approach is posited on a vision of a disembedded, self-regulating market. Putting it into practice is thus a retrograde step which will only exacerbate the problems created by the market-based corporate governance strategies which have prevailed since the late 1970s onwards.
\end{abstract}

\section{Introduction}

$\mathrm{T}$ he approach of this article is to take Polanyi's notion of embeddedness and use it to elucidate and comprehend the current conception of institutional shareholders as stewards in corporate governance. This new approach to governance requires institutional shareholders to take an active and socially constructive role in corporate governance and empowers them, both legally and morally, to do so. This article differs from contemporaneous work around shareholder stewardship because it aims to refute the idea that shareholders are capable of being useful corporate stewards in this sense. By using contextual analysis, this article contributes to the existing debate on market-based corporate governance strategies by showing that such strategies cannot thwart institutional shareholders' innate drive to seek profit maximisation regardless of the long-term effects on the company and those whom the company affects. To act as stewards for a wider public interest, institutional shareholders would need to be subject to more direct state control.

Shareholder stewardship is a paradox because shareholders lack the central quality that underpinned previous conceptions of stewardship, namely a detachment from shareownership and therefore a detachment from a sectional interest in profit. This detachment

1 With thanks to Richard Percival, Law Commission, and Professor Ralf Rogowski for their helpful comments. 
was thought to enable the steward to pursue a wider public interest. ${ }^{2}$ Previous conceptions of stewardship viewed non-owning professional management as worthy stewards of the company's best interests, precisely because they were non-owning, trained professionals. ${ }^{3}$ Directors could be good stewards because they were personally motivated by a wide range of concerns including personal achievement, good employee relations, product development and economic stability. ${ }^{4}$

The idea that large institutional shareholders may also be considered as stewards has gained momentum in recent years but, unlike the previous conceptions of stewardship, it is the fact of their ownership, indeed the very largeness of their shareholdings, which has prompted interest in their role in corporate governance. Institutional ownership not only appears to subvert the trend to dispersed ownership, evidenced by Berle in Modern Corporation, ${ }^{5}$ but the size of their holdings has led to them being reconceived as "universal owners" - owners whose stakes are so significant that their self-interest is said to be best served by ensuring general economic stability and social well being. ${ }^{6}$ In this model, institutional shareholders are thought to be predisposed to engage in socially guided investment policies. ${ }^{7}$ Indeed, as I show in section three, institutional shareholders have been keen to promote this image of the responsible, steward-like investor.

In assessing the shift to shareholder stewardship, I attempt to embrace Polanyi's theme of embeddedness as expressed in The Great Transformation. ${ }^{8}$ Polanyi's notion is that all economies, including the market economy, are embedded within society and social relations - although they differ as to the degree that they are embedded, the market economy being the most disembedded. As a response to the neoclassical economists' claim that the market economy sits independent from society as a whole - a claim which is also made by neoliberalism - Polanyi stated:

Economic history reveals that the emergence of national markets was in no way the result of the gradual and spontaneous emancipation of the economic sphere from governmental control. On the contrary, the market has been the outcome of a conscious and often violent intervention on the part of government which imposed the market organisation on society for non-economic ends. ${ }^{9}$

The market economy is the least "natural" to human social living and the most disembedded from natural social relations. It is therefore the most in need of state intervention to secure its existence.

Similarly, it can be argued that the neoliberal project from late 1970s was a political project to dis-embed the economy from social relations and to ideologically promote the market economy as self-regulating. In respect of corporate governance, the market was promoted as the most efficient regulator. However, as this article shows, the "selfregulation" of market players has in fact involved and necessitated a great deal of state intervention. In Polanyi's terms, because the market economy is inherently incompatible

2 M Dodd, "For whom are managers trustees?" (1932) 45 HLR 1145.

3 A A Berle, The American Economic Republic (Harcourt: Brace and World 1963).

4 T Donaldson and J Davis, "Boards and corporate performance - research challenges and conventional wisdom” (1994) 2 Corporate Governance: An International Review 151.

5 A A Berle and G C Means, The Modern Corporation and Private Property (Harcourt: Brace and World 1968 [1932]).

6 J Hawley and A Williams, The Rise of Fiduciary Capitalism: How institutional investors can make corporate America more Democratic (Philadelphia: University of Pennsylvania Press 2000).

7 J Hawley and A Williams, "Universal owners and SRI" in P Camejo (ed.), The SRI Advantage (Canada: New Society Publishers, 2002).

8 K Polanyi, The Great Transformation. The political and economic origins of our time (Boston: Beacon Press 2001 [1944]).

$9 \quad$ Ibid. p. 258. 
with natural human existence, or disembedded, it requires substantial state intervention to operate. Rather than state intervention being antithetical to the market, it is essential to discipline people into adhering to their "unnatural" market roles.

By contrast, in New Deal or progressive America and in post-war UK, governments (and indeed the general international consensus on macroeconomics) consciously drew together social outcomes and the economy. Government policy embedded the economy, to promote stability and equality and to meet the problems caused by the financial crisis of the late 1920s in the US, and by post-war need in the UK; and thus both governments deprioritised shareholders' interests. Put another way, by decommodifying social relations of production it was able to meet social need.

The article is structured into four parts. Throughout these sections I use Polanyi's embeddedness to further my analysis of stewardship in social and historical context. In section one, I show how stewardship was first exercised as a deliberate policy technique by the state in tandem with management in the interests of the wider public. However, the proceeding neoliberal model from the 1970s charged management with stewardship in the interests of shareholders alone. In section two, I show how the neoliberal response to, first, corporate collapse and then, more recently, financial crisis was to preserve the free market shareholder primacy model by more state intervention to bolster self-regulation. In section three, I show how shareholder stewardship has been promoted, first, by institutional shareholders themselves and, secondly, through soft and hard law. In section four, I show that institutional shareholders are a heterogeneous group similar only in their inability to make a positive impact on corporate governance.

Shareholder stewardship envisages shareholders actively influencing management to deliver shareholder value in contrast to the shareholder primacy model where governance mechanisms were designed to ensure that management delivered value to the essentially passive shareholders. Furthermore, shareholder stewardship reconceptualises shareholder value itself as an (idealised) long-term investment through which socially desirable goals are pursued; "enlightened shareholder value", in the language of company law reform in the UK. Shareholder stewardship seeks shareholders' involvement through, largely, soft law mechanisms. Its aim is that institutional shareholders will ensure a less rapacious form of capitalism because the rapacious capitalism, which was the result of the shareholder primacy model, delivered corporate and financial crisis.

In this article, I maintain that there is little to suggest that shareholder stewardship will be any less destructive or rapacious than shareholder primacy, indeed, it is counter-intuitive to suppose that shareholders will be more moderate in their demands for shareholder value than management.

\section{The historical origins of shareholder stewardship}

\section{THE STATE AND MANAGEMENT AS STEWARDS OF THE COMPANY IN THE INTERESTS OF THE WIDER COMMUNITY}

Stewardship governance was traditionally posited on the existence of a controlling but nonowning management. The most famous early exposition of this development was the empirical and analytical work of Modern Corporation. ${ }^{10}$ In this book, Berle showed how massive share dispersal in large corporations had resulted in revolutionary changes in

10 Berle and Means, Modern Corporation, n. 5 above. 
ownership and control. ${ }^{11}$ Berle argued that share dispersal had fundamentally transformed the nature of share-ownership because, as responsibility was devolved to management, shareholders could not (logically or normatively) demand the extensive rights generally attributed to private property. Shareholders had effectively "surrendered the right that the corporation should be operated in their sole interest" and had accordingly "released the community from the obligation to protect them to the full extent implied in the doctrine of strict property rights". ${ }^{12}$ Accordingly, shareholders were entitled to modest returns on their investment, after the claims of the community, labour in particular, had been met. Berle's analysis was a conscious recognition that society could, and indeed should, use the economy to meet social ends. And, although Berle initially saw the state as guiding the company to this end, he came around to the view (maintained earlier by others) that directors were also principal stewards in delivering governance for the wider community.

Modern Corporation importantly provided information and direction to the New Deal administrators about the challenges they faced in the economy and why it should be regulated. Berle's role in the administration added force to this. ${ }^{13}$ The ability of the New Dealers to regulate the economy to this degree was premised on an unashamed interventionist policy. ${ }^{14}$ Key to this, noted Polanyi, was the abandonment of the Gold Standard which removed the power of financial markets to dictate social policy. ${ }^{15}$ As a model for enhancing the stewardship of states it was later adopted by other countries and internationalised in the post-war period by arrangements such as the 1944 Bretton Woods agreement. Reduced capital movement across borders enhanced the ability for national adjustments to be made in respect of employment and pricing policies, which helped many national economies to pursue welfare-orientated policies. In the UK, this included the nationalisation of key industries, the empowering of unions and the bolstering of socially orientated funds, particularly pension funds, though tax and dividend reforms. Nationalised industries were designed to provide secure employment for millions, to stabilise the price of basic commodities, and to contribute to the well-being of the community. Their ethos and institutional goals were thought to infect the operations of private industries. ${ }^{16}$

However, the post-war, Keynesian or consciously embedded economy consensus was shaken by economic industrial crises in the 1970s. Both the economy and ideas about the economy were to take a radical shift toward the right. Thus, of the two great books written at the end of the war, Polany's Great Transformation and Hayek's Road to Serfdom, ${ }^{17}$ it was the latter's ethos that began to prevail. In the UK, recession and public debt caused fatal rifts in the delicate balance of power between the tripartite powers of unions, management and state. Years of industrial unrest had fragmented traditional political positions and in 1979 the Conservative party under Margaret Thatcher was voted into government with a new radical, neoliberal agenda. Likewise, in the US, recession and the threat of global competition saw the New Right under Ronald Reagan come into power with a similar agenda; to promote a free market and to strip away non-market, state-centred regulation.

11 In this analysis, Berle differed from the previous work because he saw the progressive possibilities from those changes to the nature of the modern corporation: W Ripley, Main Street and Wall Street (Boston: Little, Brown \& Company 1927); L D Brandeis, Other People's Money: And how the bankers use it (Connecticut: Martino Publishing 2009 [1917]); T Veblen, The Theory of Business Enterprise (New York: Cosimo 2005 [1904]).

12 Berle and Means, Modern Corporation, n. 5 above, p. 312.

13 W W Bratton and M L Wachter, "Shareholder primacy's corporatist origins: Adolf Berle and The Modern Corporation" (2008) 34 Journal of Corporation Law 99.

14 J K Galbraith, The New Industrial State (New York: Houghton Mifflen Co. 1967).

15 Polanyi, The Great Transformation, n. 8 above, p. 237.

16 A Crosland, The Future of Socialism 50th edn (London: Robinson Publishing 2006).

17 F Hayek, The Road to Serfdom (Chicago: University of Chicago Press 1944). 
Thatcherism and Reaganism thereby became synonymous in policy objectives and ideological imperatives in the context of the economy and welfare reform. In the academies, a sophisticated neoliberal model of the corporation was being developed.

\section{THE FASHIONING OF NEOLIBERAL CORPORATE GOVERNANCE AND MANAGERS AS STEWARDS OF SHAREHOLDER INTERESTS}

In the academies, a neoliberal corporate governance model replaced the old social model. This model, which I shall term the shareholder primacy model, claims that the pursuit of shareholder value should be the sole guiding force behind management decision-making. In so doing, it embraces two key themes, that of contractarianism and that of efficiency. Contractarianism conceives of the corporation as being a nexus of contracts, ${ }^{18}$ so that, in Jenson and Meckling's words, "it makes little or no sense to try to distinguish those things that are 'inside' the firm (or any other organisation) from those things that are outside of it". 19 The company is merely the market in another guise. In this way, the whole notion of "ownership as entitlement" which Berle had so apparently successfully debunked is sidestepped. The rights to which shareholders are entitled come not from their ownership of property but from the terms they have negotiated in their contract with management. In this approach, the arrangement between management and shareholder involves some "agency costs" (instances when the manager may be guided by self-interest rather than the interest of shareholders), which must be addressed by joining managerial goals with shareholder goals or by mechanisms which penalise managerial self-interest.

The argument based on efficiency ${ }^{20}$ asserts that more efficient outcomes are achieved when management narrowly focuses on shareholders' interests. Shareholder value is therefore morally justifiable on utilitarian grounds and does not rely on ownership claims to justify its use. ${ }^{21}$ Shareholders act as dummies or stand-ins for the most efficient governance orientation because representing shareholder interests is simply the most effective mechanism for achieving efficient outcomes. ${ }^{22}$

Each of these themes can be seen as an ideological attempt to dis-embed the economy and assert that it is self-regulating. The dispersal of ownership that Berle had identified was still evident, but these approaches do not rely on "true" ownership to justify claims for the primacy of shareholders' interests. However, the paucity of the claims of neoliberal corporate governance can be seen when looking at the central market mechanism for achieving efficiency or lowering agency costs, the hostile takeover. First, it is clear that the so-called market for corporate control through hostile takeovers could not have increased shareholder value if it were not for the previous corporate policy of retaining earnings. Second, although this market isn't directly controlled by the state, it has developed a framework of controls over takeovers which tend to a shareholder primacy outcome.

On the first point, a study in 1952 showed that only 52 per cent of corporate earnings (revenues after taxes, running costs and sales) were paid out in dividends, 46 per cent of

18 Originating with A A Alcian and H Demsetz, "Production, information costs, and economic organisation" (1972) 62 American Economic Review 777, p. 778.

19 M Jensen and W Meckling, "Theory of the firm: managerial behaviour, agency costs and ownership structure" (1976) 3 Journal of Financial Economics 305.

20 Coase's emphasis on efficiency envisaged the most efficient outcome as the necessary result of market relations no matter from what position the parties began transacting. Coase's theorem inspired new more proactive thinking on promoting efficiency.

21 A West, "Corporate governance convergence and moral relativism" (2009) 17 Corporate Governance: An International Review 107.

22 H Demsetz, "Information and efficiency: another viewpoint" (1969) 12 Journal of Law \& Economics 1, p. 6. 
shares purchased by private individuals were for long-term investments and 75 per cent of all transactions had been for investment purposes rather than speculation. ${ }^{23}$ Mitchell argues that the increase in share price in the post-war period to the 1960 s came from retained earnings. Thus, when changes in regulation facilitated an explosion in hostile tender bids, successful bidders using high-yield debt had access to asset-rich companies at knock-down prices, based on deflated share prices. The large oligopolies of the New Deal did not make shareholder value a governance priority, in part reflecting the community ideal. ${ }^{24}$ This newfound wealth was not created because of market efficiency but because the government had enabled investors to get access to corporate wealth.

In the UK in the post-war period, companies had also become untapped piggy banks whose shares and assets were grossly undervalued. This was in large part because of government policies to restrict dividends and because the value of company assets had rapidly increased. Here, hostile takeovers began in the 1950s (following the better financial disclosures required by the Companies Act 1948) ${ }^{25}$ but did not become an established feature of the UK economy until the 1980s, partly because of management resistance to them. Charles Clore's hostile takeover of Sears in 1953 was the first successful hostile takeover bid which was able to exploit the advantages of the post-1948 environment but many attempts followed this. So, in response to the threat of further hostile takeovers, many companies began to take defensive measures. ${ }^{26} \mathrm{~A}$ study of a sample of companies showed that anti-takeover measures (including dual shares and voting restrictions on some shares or share blocks by insiders) increased from 3.7 per cent in 1950 to 11.1 per cent in 1965.27 Alternatively, a number of companies sought protection from hostile takeovers through the use of a protective parent company. For example, Whitbread had substantial stakes in many smaller breweries to protect it from unfavourable alternative takeovers, forming what was known as the "Whitbread Umbrella".28

Government policy in the UK enabled shareholders, or to be more precise, institutions which owned shares, to thwart management resistance to takeovers. In 1959, institutional shareholders formed part of a committee set up in that year to self-regulate takeovers. The committee devised a voluntary code of conduct to regulate takeover bids which emphasised shareholder primacy and promoted a shareholder's choice to sell, timely information and board neutrality. ${ }^{29}$ This was followed by the 1968 City Code on Takeovers which emphasised shareholder choice and included a general ban on frustrating actions without the approval of the shareholders. The code was overseen by the Takeover Panel which was comprised in part by institutional shareholders. ${ }^{30}$ Polanyi's assertion that "the road to the

23 Lawrence Mitchell, using evidence gained from a NYSE study cited in L Mitchell, "Financialism: a (very) brief history" (2010) 43 Creighton Law Review 323; P Zumbansen and C Williams (eds), The Embedded Firm (Cambridge: CUP forthcoming); GWU Legal Studies Research Paper, available at SSRN: http://ssrn.com/abstract=1655739 (last accessed 10 October 2010).

24 As W Reich put it, following the New Deal period, Americans gained as employees and as citizens - although not as shareholders or consumers. W Reich, Supercapitalism: The transformation of business, democracy, and everyday life (Knopf: Borzoi Books 2007).

25 L Hannah, "Takeover bids in Britain before 1950: an exercise in business "pre-History"” (1974) 16 Business History 65.

$26 \mathrm{~J}$ Armour and D Skeel, "Who writes the rules for hostile takeovers, and why? The peculiar divergence of US and UK takeover regulation" (2007) 95 Georgetown Law Journal 1727, p. 1768.

27 J Franks, C Mayer and S Rossi, “Ownership, evolution and regulation” (2006) http://papers.ssrn.com/ sol3/papers.cfm?abstract_id=354381, p. 11 (last accessed 4 September 2011).

28 Ibid. p. 4.

29 Issuing Houses Association, Notes on Amalgamation of British Business (London: Issuing Houses Association 1959), available at http://nla.gov.au/nla.aus-vn4764542 (last accessed 1 August 2010).

30 Armour and Skeel, "Who writes the rules?", n. 26 above. 
free market was opened and kept open by an enormous increase in continuous, centrally organised and controlled interventionism" 31 is thus evidenced in UK takeover regulation.

In both the UK and US, the political question of why speculative investors who were funding takeovers on massive leverage should take advantage of accumulated value in companies, while communities and workers lost out, was answered in the academy. Managers were contractually bound to pursue shareholder value and to resist a takeover because it was not in the interest of the community and would be a breach of their contract with shareholders. This is not because shareholders are entitled to managerial attention by dint of ownership; ownership is otiose in this arrangement. The enabling of hostile takeovers in the shareholder primacy model was said to enhance the availability of accurate information on the efficiency of a company in an accessible form. Furthermore, hostile takeovers were justifiable and desirable because they reduced agency costs caused by selfserving management by disciplining them with the threat of exposure to hostile takeovers. From the contractarian perspective, hostile takeovers ensured that managers fulfil their contractual obligations to shareholders. From an efficiency perspective, hostile takeovers created a more efficient economy by weeding out poorly performing managements.

Neoliberal corporate governance made directors stewards of shareholder interests and the state put policies into place to ensure this. Like neoclassical economics, neoliberalism claimed that the market economy was the unadulterated expression of human nature and that social relations were naturally contractual in essence. Contractual man was natural man and thus a contractual model for corporate governance was a logical extension of this. Polanyi famously turned this position on its head, showing that historically the market economy was brutally forced upon a population resistant to the breakdown of altruistic social relations and their replacement with bargained contractual relations. Similarly, the shift away from social policies to market policies in this period was not a natural expression of human nature but a reorientation to market relations imposed by the state and fashioned from the shapes left by the former policies.

\section{Neoliberal governance and corporate crisis and the green shoots of shareholder stewardship}

\section{CORPORATE COLLAPSE AND CORPORATE GOVERNANCE}

The interests of shareholders were promoted in Britain in the 1980s through such policies as transferring nationalised industries to private investors and abolishing all foreign exchange controls. Reconstructing the regulation of financial markets made international finance central to the British economy. Britain's flagging industrial economy was left to largely collapse whilst the City's investment went overseas to find high profits. Britain's transformation into a service-based economy was promoted as economic revival, the invigorating effect of the market and the triumph of individualism over collectivism where shareholder value could properly be realised.

However, by the 1990s, many of these successful companies were collapsing. In the UK, at the beginning of the decade, these included Robert Maxwell's fraud against Maxwell Communications Corporation, the collapse of the Bank of Credit and Commerce International and that of Polly Peck plc.

In the UK, the problem was translated as one of agency costs and auditing standards. Accordingly, the matter was dealt with largely through soft law mechanisms with no attempt to reign in by regulation or otherwise the supremacy of shareholder primacy. The free

31 Polanyi, Great Transformation, n. 8 above, p. 146. 
market was still the product of "deliberate state action", 32 however, that action was soft or market-based governance. The Cadbury Report's ${ }^{33}$ principal mechanism for reducing agency costs was to divide the top roles into chief executive and chair and to introduce nonexecutive directors to oversee top executive activity (monitors for the monitors). The subsequent Greenbury Report ${ }^{34}$ looked to rationalise "bonding costs", the costs of reducing agency costs so as to ensure that performance-related pay really rewarded performance. The subsequent Combined Code operated on a semi-voluntary model where listed companies were not obliged to conform to the ideal model board but must explain where they had failed to do so: the "comply or explain" model.

This model, the product of deliberate state action, enabled self-regulation within the sector and sustained the shareholder primacy/short-termism model. This is hardly surprising given the primacy given to institutional shareholders in Cadbury and subsequent reports and their designated roles in the 1998 Combined Code and its predecessors. ${ }^{35}$ Furthermore, listed companies adopted the model without it being mandatory because the market responded positively to companies that did so. Appealing to the market, adopting governance structures designed to enhance shareholder value and making the largest investors part of the process became even more of a guiding principle for management. The orientation of directors' stewardship became ever more focused on shareholders as other potential claimants for consideration were sidelined.

In the US, corporate collapse on a grand scale came later in the 1990s and the government responded with a rules-based approach to reporting requirements and corporate governance. The corporate failures included Arthur Anderson, Worldcom, Adelphia and the spectacular demise of Enron. As in the UK, the regulatory response was to control top management or chief executive officer (CEO) activity and to ensure better auditing standards. The Sarbanes-Oxley Act 2002 transformed the governance and the reporting requirements of all companies (including non-US companies). The Act requires that both the $\mathrm{CEO}$ and chief financial officer sign off the annual reports confirming that they were compliant with financial reporting requirements. The Act also gives the Securities Exchange Commission the power to require the New York Stock Exchange (NYSE) and NASDAQ to prohibit the listing of securities where the company does not have an audit committee consisting entirely of independent directors. ${ }^{36}$ In 2003, the NYSE and NASDAQ stock markets adopted additional governance rules which included a requirement to have a majority of independent directors on the board, and for independent directors to have separate and regular meetings. The NYSE rules require that each board has a nomination and compensation committee made up of independent directors. ${ }^{37}$

32 Polanyi, Great Transformation, n. 8 above, p. 147.

33 Report of the Committee on the Financial Aspects of Corporate Governance (Cadbury Report) (London: Gee \& Co. December 1992), available at www.ecgi.org/codes/documents/cadbury.pdf (last accessed 1 August 2010).

34 Directors' Remuneration, report of study group chaired by Sir Richard Greenbury, July 1995, available from http://www.ecgi.org/codes/documents/greenbury.pdf (last accessed 1 August 2010).

35 Section E. Now superseded by the UK Stewardship Code.

36 Sarbanes-Oxley Act 2002, s. 303.

37 NYSE Corporate Governance Rules 4 and 5, available at www.nyse.com/pdfs/finalcorpgovrules.pdf (last accessed 1 August 2010). 


\section{THE NEW ECONOMIC OWNERS 38}

By the 1990s, 37 per cent of equities in the US markets were owned by financial institutions rising to 60 per cent in 2006. ${ }^{39}$ In 1997, 52.7 per cent of shares in the UK market were held by institutional shareholders. ${ }^{40}$ They had been significant owners since the 1950 s, owning 18 per cent in 1957 . However, they became dominant owners over the next few decades and by 1977 they owned 58 per cent of the share market. This was accompanied by a corresponding fall in individual ownership so that, while individuals held nearly 70 per cent in 1957, by 1977 they owned less than 30 per cent. In contrast, institutional shareholders owned only 7 per cent of the US markets in $1950 .{ }^{41}$ The disparity between the two countries may be explained by the UK's post-war corporatist government policy which sought to bolster organisations and to undermine private share-ownership. Institutional investment was encouraged through dividend tax policy ${ }^{42}$ which, at the same time, penalised individual shareholder's income. The top marginal rate for individual shareholders was 90 per cent until 1979. In contrast, institutional shareholders, such as insurance companies, enjoyed extensive tax relief while pension funds were entirely exempt from tax. As a result, institutions rapidly increased their ownership of shares. ${ }^{43}$

Not surprisingly, in both countries, institutional shareholders gained attention and voice when they gained financial significance as shareholders. In the UK, as noted earlier, institutional shareholders formed part of the self-regulating body which managed takeovers and designed rules which specifically favoured investors' interests and developed mechanisms to ensure they were followed.

In the US, institutional shareholder ownership precipitated a growing academic debate over shareholder empowerment and the governance role of shareholders. ${ }^{44}$ The important clout of American corporate law scholarship soon brought institutional shareholders to everyone's attention. Institutional shareholders, unlike Berle's dispersed shareholders, had the economic strength to enforce contractual claims against managers and to reduce agency costs so they seemed to scholars and policymakers ideally placed to act as "monitors". Importantly, their level of ownership was substantial enough to bridge the gap between ownership and control, described in Modern Corporation, and thus to enable neoliberal thought to reassert shareholder entitlement as ownership entitlement. ${ }^{45}$

However, the fledgling enthusiasm for institutional shareholders dissipated from the mid-1990s because of their evident aversion to influencing internal corporate affairs. Increasingly, eminent commentators raised doubts over their efficacy. John Coffee noted

38 A phrase used by De Vroey to differentiate controlling shareholders from other shareholders. M De Vroey, "The separation of ownership and control in large corporations" (1975) 7 Review of Radical Political Economics 1, p. 3.

39 M Kahan and E B Rock, Embattled CEOs, University of Pennsylvania Institute for Law and Economics Research Paper No 08-25, 2008; New York University Law and Economics Research Paper No. 08-43; ECGI, Law Working Paper No 116/2009, available at SSRN http://ssrn.com/abstract=1281516, p. 9 (last accessed 10 October 2010).

40 I Hill (ed.), Share Ownership: A report on the ownership of shares at 31st December 1997 (London: The Stationery Office 1999), para. 2.2. This had a combined value of $\_669 \mathrm{bn}$ of which $f^{290 \mathrm{bn}}$ was held by insurance companies.

41 Ibid. para. 2.2.

42 Armour and Skeel, "Who writes the rules?", n. 26 above.

43 Ibid.

44 B S Black, "Agents watching agents: the promise of institutional investor voice" (1992) 39 UCLA Law Review 811, pp. 827-8; E B Rock, “The logic and (uncertain) significance of institutional shareholder activism” (1991) 79 Georgia Law Journal 445, p. 447.

45 In the UK, this model had been mainly retained. 
their extreme passivity. ${ }^{46}$ Furthermore, he found that, in the UK, liquidity was of utmost importance for institutional shareholders. This implied a lack of long-term commitment and therefore a correlative lack of interest in monitoring corporate activity. ${ }^{47}$ Corporate Codes continued to appeal to them and some academics remained enthusiastic supporters of their entitlement as owners but much of the original expectation had gone. The financial crisis of 2008 changed all that and institutional shareholders were once again crowned as the princes of corporate monitoring.

\section{The coming of shareholder stewardship}

\section{AN OVERVIEW}

There are differing explanations for the current crisis. Some cite risky business strategies, ${ }^{48}$ or the emergence of intricate obfuscating financial packages, ${ }^{49}$ or regulatory capture. ${ }^{50}$ But what underlines these explanations is that the crisis was driven by short-term profit maximisation imperatives. In recognition of this, the most recent post-crisis corporate governance initiatives have emphasised long-term goals rather than short-term shareholder returns. Given this premise, it might seem perverse that a major part of the armoury for this restraint is the empowerment of shareholders themselves. However, reconceptualised as stewards, institutional shareholders have indeed been charged with ensuring the longterm stability and social responsibility of corporations.

There is some logic to this given the "easy" reason for the financial crisis; managerial greed manifested in high remuneration packages. Institutional shareholders may have a selfinterest in ensuring that there has indeed been "pay for performance" and could use their voting power to register their assessment of that performance. ${ }^{51}$ But, while institutional shareholders may have a role to play in assessing management pay, it is quite a leap to view them as willing and competent to act as guardians of corporate stability and long-term development. In so doing, I believe that governments are being seduced by the rhetoric of institutional shareholders' activism.

\section{INSTITUTIONAL SHAREHOLDERS ON WHY THEY ARE TRUSTWORTHY STEWARDS}

The financial crisis has given fresh impetus to institutional shareholders' involvement in corporate governance issues, which had already been emerging over the last 10 years or so. In the crisis context, their claim to be responsible and steward-like has been uncritically accepted. Many investors have strong informal ties with government organisation concerned with good governance. Most investors in the UK are represented by principle investor trade associations, the Association of British Insurers, the Investment Management Association

46 B S Black and J C Coffee, "Hail Britannia?: Institutional investor behavior under limited regulation" (19931994) 92 Michigan Law Review 1997.

47 J C Coffee, "Liquidity versus control: the institutional investor as corporate monitor" (1991) 91 Columbia Law Review 1277.

48 Banks started to act like every other corporation and abandoned their traditional low-risk approach, deprioritised their creditors and prioritised their shareholders. New regulation facilitated this by allowing them to make risky loans and then to financialise those loans; selling them off as commodities, known as collateralised debt obligations.

49 L E Talbot, "Of insane forms. From collectives to management controlled organisations to shareholder value organisation: building societies a case study" (2010) 11 Journal of Banking Regulation 223.

50 D G Tarr, "The political, regulatory and market failures that caused the US financial crisis", 27 December 2009, available at SSRN http://ssrn.com/abstract=1322297 (last accessed 10 October 2010).

51 Shareholders may approve or otherwise the Directors Remuneration Report, Companies Act 2006, s. 439. 
and the National Association of Pension Funds. ${ }^{52}$ These associations are led by the Institutional Shareholders Committee (ISC) which sets out best practice in its Code on the Responsibilities of Institutional Shareholders (ISC Code). This code is revised in line with the Combined Code. In return, it retains significant voice in current regulative initiatives, for example, in maintaining a dialogue with the Financial Reporting Council (FRC).

Other investors are increasingly vocal about their engagement in wider societal issues, frequently taking on specialist advisors, such as Pensions Investment Research Consultants, ${ }^{53}$ to advise on socially responsible investment (SRI). Similarly, Hermes, which is wholly owned by the British Telecom pension scheme, manages 181 clients with total assets of $f_{24.6 \mathrm{bn}}$. Hermes advocates "responsible ownership" and recommends that listed companies should adopt a number of principles it associates with good performance before it will advise its clients to invest. ${ }^{54}$

The giant of institutional shareholder organisations, the International Corporate Governance Network (ICGN) advises institutional investors (as well as the myriad of agents and advisors) to embrace both corporate social responsibility (CSR) and SRI by engaging with companies to ensure their commitment to long-term, sustainable investment and to ensure good governance practices. ${ }^{55}$ ICGN represents members from 38 countries including professionals and policymakers as well as institutional investors managing capital in excess of $\$ 10$ trillion. ${ }^{56}$ CSR became impossible for big companies to ignore (or to be seen to ignore). 57

The trend amongst investors toward SRI has crystallised as an approach around the United Nations initiative, the Principles for Responsible Investment (PRI). ${ }^{58}$ PRI is a set of best practice guidelines for investors who wish to invest according to environmental, social and corporate governance (ESG) criteria. 59 The principles themselves were heavily influenced by the involvement of 20 large institutional shareholders from 12 countries, ${ }^{60}$ as well as reflecting the social aspirations of Global Compact in alerting corporations to human rights issues. ${ }^{61}$ Compliance with PRI is (like that of Global Compact) through selfreporting. In the former case, this is through an annual PRI reporting and assessment survey in which members must undertake and show some progress in promoting ESG investment. ${ }^{62}$ Members who consistently fail to show progress in their investment policies face possible delisting. The principles are self avowedly "voluntary and aspirational". ${ }^{63}$

The trend toward SRI, or ESG (the currently preferred acronym), conflates what is good for society with what is good for institutional investors. Indeed, the PRI baldly states

52 For example, amendments to the Pensions Act in 2000 require occupational pension funds to show how they incorporate social and environmental concerns in their investment policies.

53 Pensions Investment Research Consultants Ltd, www.pirc.co.uk/ (last assessed 10 August 2010).

54 Hermes Equity Ownership Services Ltd, www.hermes.co.uk/files/pdfs/The_Hermes_Ownership _Principles.pdf (last accessed 4 March 2010).

55 ICGN Principles, www.icgn.org/files/icgn_main/pdfs/best_practice/inst_share_responsibilities/ 2007_principles_on_institutional_shareholder_responsibilities.pdf (last assessed 10 August 2010).

56 International Corporate Governance Network, www.icgn.org (last assessed 1 August 2010).

57 D Franklin "Just good business", The Economist, 19 January 2008 (386(8563)), pp. 3-6.

58 UN Principles for Responsible Investment, available at www.unpri.org/principles/ (last assessed 1 August 2010).

59 Ibid. p. 2.

60 Ibid.

61 UN Global Compact, available at www.unglobalcompact.org/ (last assessed 1 August 2010).

62 UN Principles for Responsible Investment, n. 58 above, p. 8.

63 Ibid. p. 2. 
that, "applying the Principles should not only lead to long term financial returns but a closer alignment between the objectives of institutional investors and those of society at large". The PRI mission for institutional shareholders to prevail upon corporate management to further enhance CSR operates to construct institutional shareholders as corporate stewards.

In the wake of the financial crisis it is a claim that the UK government has been content to accept. Thus, the Walker Review in 2009, set up to propose reforms to the governance of banks and other financial institutions (as governance failure was believed to have contributed to the financial crisis), sought the contribution of the ISC. The Walker Review recommended more shareholder involvement in governance monitoring, Furthermore, as a result of this review, the FRC brought forward its own review of the Combined Code so as to harmonise the governance of all listed corporations at the same time. As a result of this review, the FRC concluded that shareholder monitoring of the code should be enhanced as an effective mechanism to improve corporate governance. ${ }^{64}$ To this end, the FRC produced the Stewardship Code (2010) which followed the recommendation of the Walker Review that the code should adopt the ISC Code on the Responsibilities of Institutional Investors. ${ }^{65}$

The guidance in the Stewardship Code is aimed, at first instance, at fund managers who are required to "comply" with this guidance or "explain" why they have not done so on their websites. Lacking the teeth of even the current Combined Code's application to listed companies, the Stewardship Code provides little censure or incentive to comply. Investment firms that publish their compliance on the website enjoy the doubtful honour of being listed on the FRC's website. Yet, despite the minimal monitoring requirements and the absence of censure for non-compliance, the Stewardship Code begins with the stated hope that this will "help long term returns", a new stable economy. 66

In the US, the degree to which shareholders should be part of the corporate governance process has polarised academic discussion over the last few years, with some arguing for the enhancement of shareholder empowerment ${ }^{67}$ and others arguing for shareholder disempowerment ${ }^{68}$ and director primacy. ${ }^{69}$ Earlier reform had assisted the shareholder empowerment lobby. For example, in 1992 the SEC substantially amended the proxy rules to enable shareholders to communicate more easily in proxy solicitations by requiring companies to include shareholders' resolutions in its own materials. ${ }^{70}$ The financial crisis has dramatically enhanced the trend to shareholder involvement in corporate governance as a bulwark against avaricious and irresponsible management. ${ }^{71}$ In the USA, the Emergency

64 FRC, Consultation on a Stewardship Code for Institutional Shareholders (London: FRC January 2010), available at www.frc.org.uk/images/uploaded/documents/Stewardship \%20Code $\% 20$ Consultation $\% 20 J a n u a r y \% 202010$. pdf (last assessed 1 August 2010); D Walker, "A review of corporate governance in UK banks and other financial industry entities" (London: July 2009), available at www.hm-treasury.gov.uk/d/ walker_review_consultation_160709.pdf (last assessed 1 August 2010).

65 With some amendments to encourage more interaction between investors and management and to require attendance at AGMs, FRC, Implementation of the UK Stewardship Code 2010 (London: FRC July 2010), p. 4, available at: www.frc.org.uk/images/uploaded/documents/Implementation $\% 20$ of $\% 20$ Stewardship $\% 20$ Code\%20July\%2020103.pdf (last assessed 1 August 2010).

66 FRC, Consultation, n. 64 above, p. 10.

67 L A Bebchuk, "The case for increasing shareholder power" (2005) 118 Harvard Law Review 833.

68 W W Bratton and M L Wachter, "The case against shareholder empowerment" (2010) 158 University of Pennsylvania Law Review 653; L A Stout, "The mythical benefits of shareholder control” (2007) 93 Virginia Law Review 789.

69 S Bainbridge, "Director primacy and shareholder disempowerment" (2005-06) 119 Harvard Law Review 1735.

70 Rule $14 \mathrm{a}-8$ of the Securities Exchange Act.

71 Bebchuk, "The case for increasing shareholder power", n. 67 above. 
Economic Stabilisation Act of 2008 introduced "say on pay" mandates for those institutions enjoying the Troubled Asset Relief Program (TARP). Similarly, the Shareholder Bill of Rights Act introduced to the US Congress in $2009^{72}$ conveyed much of the message about the centrality of shareholder empowerment in current thinking. ${ }^{73}$ In introducing the Bill, Senator Schumer stated that:

during this recession, the leadership at some of the nations most renowned companies took too many risks and too much in salary, while their shareholders had too little to say. This legislation will give stockholders the ability to apply the emergency brakes the next time the company management appears to be heading off a cliff.

What is interesting about this debate is that it trails reality. Shareholders' had a great deal to say before the financial crisis and management was already divesting itself of power in response to shareholder demands. For example, because, shareholders thought the market in corporate control did indeed optimise shareholder value, corporations had already largely abandoned staggered boards (the most effective defence against hostile takeovers), with only 16 per cent of companies having them in 2008 compared to 44 per cent in $1998 .{ }^{74} \mathrm{Ed}$ Rock's work also evidences how much CEOs listened to what institutional shareholders had to say, so that, by 2008, 18 Standard \& Poor (S\&P) 100 companies used plurality voting (which assures that all nominated directors are generally elected, thus a desirable outcome for management), down from 90 in 2003.75 Rock observed that in all cases "boards just caved in to demands for majority voting". ${ }^{76}$ None of this provided protection against corporate failure. The 15 worst-performing stocks in the S\&P 500 companies were less likely to have staggered boards and no more likely to have poison pills than the best performers. ${ }^{77}$ Indeed, 80 per cent did not have staggered boards, 80 per cent did not have a poison pill in place and 73 per cent had a majority-voting or director-resignation policy.

In both the UK and the US, from the late 1970s, directors as stewards for shareholders anticipated what shareholders would want. As institutions increased their ownership of shares, neoliberal governance sought (through the codes) the views of the now more identifiable owners. Over this period, we saw successive corporate scandals and then global financial crisis. The current response to crisis retains market-based corporate governance strategies, but now requests institutional investors to be more active. It requires them to be the stewards, partly prompted by institutions' own claims to socially responsible activities. In the final section, I assess the veracity and efficacy of institutional stewardship.

\section{Institutional shareholders as stewards}

\section{WHO ARE THEY AND HOW DO THEY BEHAVE?}

In order to be good stewards, institutional shareholders need to be both active in corporate governance and guided by social responsibility. However, institutional shareholders only seem active when engaged in social irresponsibility and rapaciousness, otherwise they are

72 Shareholder Bill of Rights Act 2009, 111 th Congress s. 3 by Senator Schumer.

73 This did not become law having been superseded by many provisions in the Dodd-Frank Act 2010.

74 Bratton and Wachter, "The case against shareholder empowerment", n. 68 above, p. 679.

75 Kahan and Rock, Embattled CEOs, n. 39 above.

76 Ibid. p. 24.

77 Statistics from Wachtell, Lipton, Rosen and Katz, available at www.law.harvard.edu/.../corporate-governanceand-the-financial-crisis-causes-and-cures.PPT (last accessed 26 July 2010). They cite the worst performers as Lehman Brothers, Washington Mutual, Fannie Mae, Freddie Mac, AIG, Circuit City, General Growth Properties, EW Scrips, Ambac Financial, XL Capital, American Capital, Bear Stearns, National City, Genworth Financial, Developers Diversified. 
inactive. Broadly speaking, pension funds fall into the latter category, hedge funds in the former. Pension funds have the largest proportion of shareholdings with public pension funds in the US holding "approximately $20 \%$ of publicly traded US equity (or $\$ 2.5$ trillion) at the end of 2004-5". ${ }^{78}$ Since the financial crisis, the value of equities has fallen considerably so that the UK stock market, valued at $f_{1158.4}$ billion in 2006 has fallen to f699.8billion (or by 37.7 per cent) since the end of $2008 .{ }^{79}$ However, the proportion of shareholdings owned by different institutions has remained fairly constant with pension funds owning 12.8 per cent of all UK equity value. ${ }^{80}$ The lower proportion of equities held by pension funds in the UK market is a result of the increasingly internationalised character of this market. In 2008, 41.5 per cent of UK equities were owned by foreign investors, up from 11.3 per cent in 1990.81

Despite the differences between the US and UK markets, pensions still hold a significant proportion of total equities, however, few utilise it to any effect, let alone as stewards. Recent work on pension funds' governance activity in the US concluded that they have "a very limited spectrum of activities" where "smaller funds delegate more function to active portfolio management and proxy advisory services, such as Institutional Shareholder Services (ISS)". 82 This study found that 53.9 per cent of the funds never submitted a letter to management, and 64 per cent never met with management. ${ }^{83}$ They found that public pension funds did not tend to pursue the company-specific forms of activism which impact on corporate governance. ${ }^{84}$ Furthermore, they found that public pension funds had very little familiarity "with existing empirical evidence on corporate governance, such as studies analysing the value of poison pills, independent boards, or shareholder litigation". 85 This evidence suggests that pension funds largely do not have the tools to be successful activists, let alone successful stewards.

Pension funds remain the largest of the institutional shareholders in the US ${ }^{86}$ (insurance companies are the largest in the UK with 13.4 per cent of total equities in 2008), ${ }^{87}$ however, they are not the fastest growing. Thus, the governance potential of institutional shareholders must also be assessed by observing the activity of mutual funds whose holdings in the US rose from 7 per cent in 1990 to 28 per cent in 2006. Rock cites the activities of Fidelity, Lord Abbett \& Co. and Morgan Stanley, which led a campaign to get the New York Time Co. to alter its share structure (which assured control for the founding family, Sulzberger), among other campaigns. ${ }^{88}$

However, while these funds are clearly powerful, they are far from stewards. Most institutional shareholders are more concerned with short-term profits and only differ as to

78 S J Choi and J E Fisch, "On beyond CalPERS: survey evidence on the developing role of public pension funds in corporate governance” (2008) 61 Vanderbilt Law Review 315, pp. 316-17.

79 Office for National Statistics (ONS), Statistical Bulletin, "Share Ownership Survey 2008” (London: ONS January 2010), p. 1, available at www.statistics.gov.uk/pdfdir/share0110.pdf (last accessed 1 August 2010).

80 Ibid.

81 Ibid. p. 6. Another quirk of investment shifts since the crisis has been the increase of public sector holdings from $0.1 \%$ in 2006 to $1.1 \%$ in 2008 (p. 2).

82 Choi and Fisch, "On beyond CalPERS", n. 78 above, p. 318.

83 Ibid. p. 329.

84 S J Choi, J E Fisch and A C Pritchard, "Do institutions matter? The impact of the lead plaintiff provision of the Private Securities Litigation Reform Act” (2005) 83 Washington University Law Quarterly 869; NYU, Law and Economics Research Paper No 04-08.

85 Choi and Fisch, "On beyond CalPERS" n. 78 above, p. 347.

86 In 1950 private pension funds owned 1\% of total equity but by 2006 that figure was over $60 \%$.

87 ONS, "Share Ownership Survey", n. 79 above, p. 2.

88 Kahan and Rock, Embattled CEOs, n. 39 above, p. 16. 
the rapacious way they will pursue that. Hedge funds, for example, are highly rapacious. From 2001-2006, 236 activist hedge funds were involved in 1056 publicly traded targets. ${ }^{89}$ Bratton's study showed that activist hedge funds used three main strategies to increase shareholder value, which included increasing leverage, returning capital to shareholders and selling corporate assets. ${ }^{90}$ None of these does anything more than undermine a stable capital base. Further evidence of their concern with short-term gains is provided by the times in which they are active. In the bull market, they were highly active. In 2007, hedge funds conducted 137 activist campaigns which have involved giant corporations such as McDonald's, Time-Warner, Blockbuster and Kraft. However, in the bear market, where opportunities to ruthlessly pursue shareholder value have evaporated, they have withdrawn from activism to a high degree. ${ }^{91}$ In other words, they're never around when you need them.

For institutional shareholders to be effective stewards they must be both active and concerned with stewardship-like governance. In the UK, institutional shareholders are very conservative in their strategies. They invest in the largest companies and are guided by listings. In 2008, 84.3 per cent of pension funds investment in UK equities was invested in the FTSE 100 companies. $^{92}$ In the US, Professor Bushee's classification of institutional investors suggests that in fact they are mainly either inactive or active in a self-interested and non-stewardship-like way. Based on investment strategies from 1983-2002, Bushee sets out three different types of investor: "transient", "dedicated" and "quasi-indexers". 93 Transient investors, he shows, turn over 70 per cent of their portfolios each quarter and represent 31 per cent of total institutional investors. Dedicated investors were those who held onto at least 75 per cent of their stock for at least two years and represented 8 per cent of total institutional investors. The final group, quasi-indexers, maintained highly diversified portfolios but traded infrequently. They represented 61 per cent of total institutional investors. The last category, though the largest, offers little in terms of promoting corporate governance by utilising new shareholder powers as these investors have small stakes in companies and are not actively engaged in monitoring their investments. Such investors rely on diversification alone as a mechanism to increase value and to balance risk. The next largest group, the transient shareholders, are, Bushee notes, commonly involved in takeover activity and are frequently involved in overbidding for acquisitions. Bushee also noted that as institutional shareholders' fund managers refer to quarterly earnings per share (EPS) the influence of transitory investors will directly and negatively impact on research and development spending. Thus, those investors who are active are only active in the pursuit of short-term personal returns with the result that they undermine long-term productive development.

Thus, the evidence to date shows that, in the few instances where institutional shareholders are activist, it is for short-term profiteering only, not for the long-term strategic governance envisaged by shareholder stewardship.

89 A Brav, W Jiang, F Partnoy and R Thomas, "Hedge fund activism, corporate governance, and firm performance” (2008) 63 Journal of Finance 1729, p. 1739.

90 Bratton and Wachter, "The case against shareholder empowerment", n. 68 above.

91 Brav et al., "Hedge funds activism", n. 89 above.

92 ONS, "Share Ownership Survey", n. 79 above, p. 9. This is up from the 2006 survey where pension funds held $77.3 \%$ in FTSE 100 companies.

93 B J Bushee, "The influence of institutional investors on myopic R\&D investment behaviour" (1998) 72 Accountancy Review 305. 


\section{WHY INSTITUTIONAL SHAREHOLDER STEWARDS WOULD NOT HAVE MADE BETTER CHOICES THAN A SHAREHOLDER PRIMACY-DRIVEN MANAGEMENT AND AVOIDED CRISIS}

The claim in this section is that institutional shareholder stewards would have made much worse choices because not only would they be driven by shareholder primacy goals, their decision-making would have been less informed and less rational than that of a professional management. Initiatives like the Stewardship Code can do nothing to alter those fundamentals.

Institutional investors make choices about investments based on external indicators such as share price. From a neoliberal perspective, that is a good thing as share price is the most effective and accurate indicator of real value. It is the reification of rational economic actors' calculation of risk, return and current interest rates (inter alia). But is what investors think something is worth the same as what it is worth? Schiller argues that it is not. Rationality, he argues, does not primarily determine investors' choices and an "irrational exuberance" characterises much investment activity. ${ }^{94}$ In his study of the psychology of investment he shows that investors may continue to have high expectations of share prices throughout sustained periods of high price-earnings ratio $(\mathrm{P} / \mathrm{E}) .{ }^{95}$ While real rises in share values will follow periods of economic depression, this will quickly even out, although investors will continue with the expectation that real share value will rise at the same rate. Similarly, Froud et al.'s study of average returns from shares listed in the S\&P 500 from 1982-2002 showed that the rise in share prices did not correlate with the annual return on those shares. Indeed, their statistics show that annual return was frequently below the prevailing rate of interest. ${ }^{96}$ The absence of correlation between returns and share price has been variously explained as the incompetence of investors ${ }^{97}$ or the sheer volume of active investors operating in the market. In the latter explanation, demand itself has led to price increases. As Lynne Dallas points out, "concurrent with the rise of institutional shareholders has been an increased turnover of stock so that whilst only $12 \%$ of stock changed hands in 1960 this increased to 87\% in 2005".98 The rise of institutional shareholders as players in the stock market has obfuscated real value under the sheer weight of buying and selling which has inflated prices.

In their challenge to the growing shareholder empowerment hegemony, Bratton and Wachter argue that we cannot expect shareholders to make better choices than management because there are information asymmetries between the two. Investors act without all the information, and certainly with much less information than managers, therefore it is not "strong form" efficient. 99 The market cannot assimilate all relevant information and enhanced disclosure is often dismissed as too costly. Thus, they conclude, as the market can only assimilate all public information, it cannot be more than a "semi-strong form". Bratton and Wachter also cite a body of literature which shows how incompetent the market is when confronted with new technologies. Investors' inability to objectively assess the real value of shares in new technology companies results in an "irrational exuberance" or an urgency to buy which results in high-volume trading and speculative bubbles. Their

94 R Shiller, Irrational Exuberance 2nd edn (New York: Doubleday 2005).

95 Which are indicative of heavily overpriced shares, the dot.com shares having a particularly high $\mathrm{P} / \mathrm{E}$.

96 J Froud, J Sukhdev, A Leaver and K Williams, Financialisation and Strategy (London and New York: Routledge 2006), p. 78.

97 D Henwood, Wall St (New York: Verso 1998).

98 L Dallas, "Caring too much about stock prices: managerial myopia and institutional shareholders" presented at Opening Symposium for the Adolf S Berle Jr Center on Corporations, "In Berle's Footsteps", Law and Society Seattle Law School, 7-8 November 2009, p. 399.

99 Bratton and Wachter, "The case against shareholder empowerment", n. 68 above. 
position, is not, of course an argument against shareholder primacy, merely that shareholders are not competent to make decisions in their own interest and could potentially introduce more irrationality and instability into the market if allowed to do so.

Thus, despite institutional investors' claims to undertake considered and socially responsible investment such as would justify their role as stewards, the evidence suggests the contrary. It would seem that, not only would they have pursued shareholder primacy with even more alacrity than performance-pay-driven management, they would have done so in a less informed and more destructive manner. Institutional investors range from the slothful (typical in pension funds) to the rapacious (typical in hedge funds), but they all share the same lack of managerial competencies. Given this, shareholder stewardship as a mechanism to bolster better self-regulation seems to have no solid evidential foundation as to its efficacy.

\section{Conclusion}

Shifting responsibility onto shareholders in the shareholder stewardship model is an attempt to "fix" the market so that it can successfully self-regulate and avoid crisis. However, as Polanyi shows, the market fails because of its disembedded (or alienating) nature. Selfregulation can never work because it relies on ideological confidence in the market which Polanyi teaches us is only maintainable by external and frequently violent intervention. Historically, "the self-regulating market was unknown; indeed the emergence of the idea of self-regulation was a complete reversal of the trend of development". 100

Shareholder stewardship is thought to be an effective form of self-regulation because owners will more efficiently reduce the agency costs inherent in modern corporations. However, management failure to adhere to its "contractual" obligations to shareholders in seeking shareholder value was not the cause of the crises. Indeed, it was the very pursuit of profit maximisation, the very adhering to this "obligation" in an enabling environment, which has precipitated crises.

Institutional shareholders are thought to be effective stewards because they have selfadopted responsible investment codes. However, evidence shows that they are variously ill informed, inactive or self-interestedly active. It is not in their nature to be socially responsible because their interest is in profit maximisation alone. And, as this article has attempted to show, effective stewardship was traditionally posited on an absence of selfinterest in profit maximisation. Thus, management in large corporations where shareholders were dispersed were ideally placed to act as stewards where the social and economic policies of the government could ensure that the corporation was governed to meet the needs of the wider community. During such periods, a degree of re-embeddedness was assumed.

The shift to neoliberalism and market-based governance disembedded the economy again. It was because governance sought to bind management to shareholder interests that managements were no longer capable of acting as stewards. It is, therefore, even less plausible to look to institutional shareholders themselves to establish stewardship when it is they who have the greatest self-interest in profit maximisation and, arguably, the least in wider public concerns.

Shareholder stewardship will be no more effective than previous market-based governance strategies because the market is not essentially self-regulating. As the financial crisis has shown, it requires significant state intervention to ensure its existence and then to manage the social problems it causes. The neoliberals are wrong and Polanyi was right. Institutional investors cannot deliver governance which enhances long-term progress and 
stability because it is contrary to their nature, despite what their platitudinous codes and principles say. In the fable of the scorpion and the frog, the scorpion must sting the frog that is carrying him across the river and whom he has promised not to harm. He will do so even though they will both drown as a result. The scorpion's explanation? "I'm a scorpion; it's in my nature." 